\title{
CRETACEOUS INSECTS FROM LABRADOR \\ 2. A NEW FAMILY OF SNAKE-FLIES \\ (NEUROPTERA: ALLORAPHIDIIDAE)*
}

\author{
By F. M. Carpenter \\ Harvard University
}

Among the twelve insects which Professor Dorf collected near Schefferville in Labrador is a neuropteron of the suborder Raphidiodea. This is the first Cretaceous snake-fly to be found, though the group is known from older deposits, Permian as well as Jurassic (Martynova, 1961). The Labrador fossil has more in common with the Jurassic species than with the Tertiary and Recent families, Inoceliidae and Raphidiidae, but clearly represents a distinct family.

\section{Family Alloraphidiidae, new family}

Related to the Mesoraphidiidae. Fore wing very long and slender; pterostigma well-developed; Sc ending at mid-wing; Rs originating just before mid-wing; MA arising well after the fork of MP and coalesced with Rs for a short distance; $\mathrm{CuA}$ connected to $\mathrm{M}$ at its point of separation from $R$. Hind wing about the same size and shape as the fore wing; costal area narrower than that of fore wing; Sc terminating slightly beyond mid-wing; $\mathrm{MA}$ arising from $\mathrm{R}$ just beyond the origin of MP.

This family differs from the Mesoraphidiidae not only in the extreme wing-length but also in having MA in the fore wing originate well beyond the point of forking of $\mathrm{MP}$, and in having $\mathrm{CuA}$ connected to $M$ at its point of separation from $R$. In the fore wing of the Mesoraphidiidae MA arises from $M$ before or at the origin of $M P$, and $\mathrm{CuA}$ joins $M$ distad of the separation of $M$ from $R$.

\section{Alloraphidia, new genus}

Fore wing about six times as long as wide; costal area widest at about its middle; Sc directed away from the costa slightly in the apical region and giving rise to about six costal veinlets; Rs arising just basad of the end of Sc; Rs and MA each with three well-defined branches, apart from marginal forkings; $\mathrm{CuA}$ with a closed, submarginal cell. Hind wing: MA very close to MP at their origins; branches of main veins much as in fore wing.

Type-species: Alloraphidia dorfi, n.sp.

*This research has been aided by a grant from the National Science Foundation (GB-2038). 
Alloraphidia dorfi, new species

Figure I.

Fore wing: length $9.5 \mathrm{~mm}$., width $\mathrm{I} .6 \mathrm{~mm}$.; pterostigma light yellow (as preserved), short and broad and traversed by a single oblique veinlet; $\mathrm{MP}$ with four definite terminal branches; $\mathrm{CuA}$ with three branches. Hind wing length $9.0 \mathrm{~mm}$., width $\mathrm{I} .8 \mathrm{~mm}$.; pterostigma as in fore wing but slightly narrower; $\mathrm{CuA}$ with a distal fork; cross veins shown in text-figure $I$.
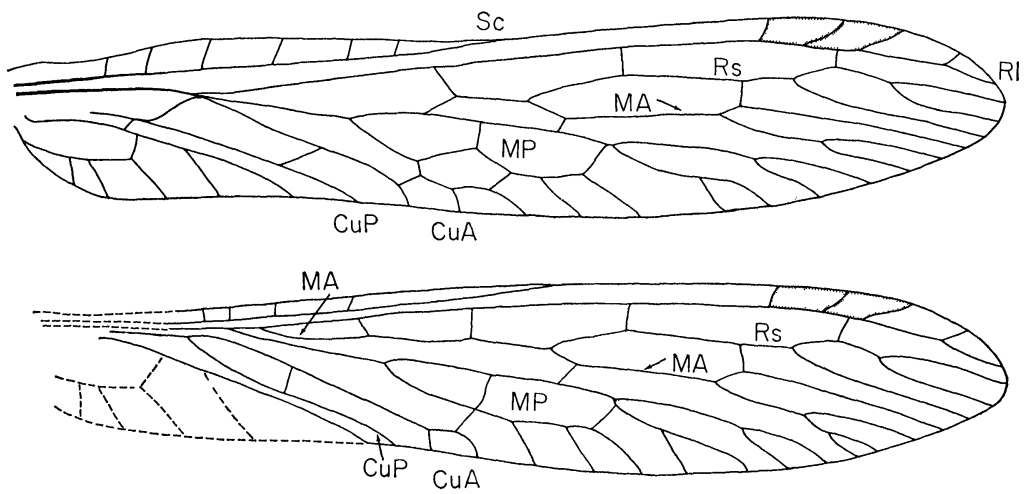

Figure 1. Alloraphidia dorfi, n.sp. Drawings of fore and hind wings, based on holotype. Length of wing, $9.5 \mathrm{~mm}$. Cretaceous of Labrador.

Holotype: No. 87269, Invertebrate Paleontology collections, Princeton University. The specimen is preserved in a piece of hard, ferruginous argillite, collected at Redmond No. I deposit in Knob Lake District (near Schefferville), Labrador, Canada. Collected by Professor Erling Dorf in 1958. This deposit is apparently late Albian (Early Cretaceous) or Cenomanian (Late Cretaceous) in age, very nearly at mid-Cretaceous.

The specimen consists of a pair of fore and hind wings virtually complete; the wings are almost perfectly superimposed but with just enough discrepancy so that the main veins can be followed separately for each wing, except for the anal area of the hind wing. The preservation is excellent; the pterostigma is light yellow, as in many Recent snake-flies.

On the basis of the wings, Alloraphidia seems to be much closer to the Mesoraphidiidae than to the Recent families of the order. 

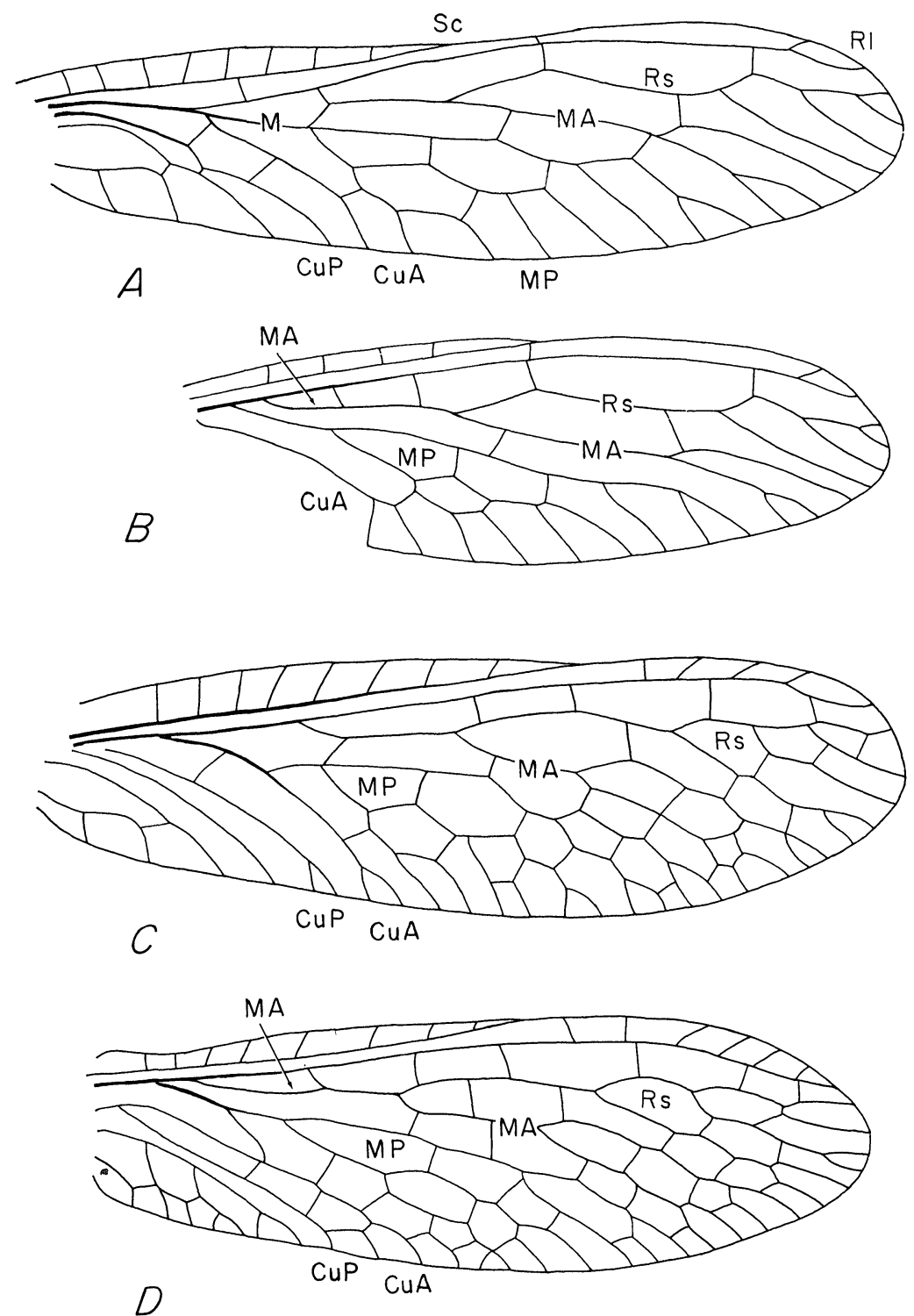

Carrenter - SNake-FLies 
In the Alloraphidiidae and Mesoraphidiidae MA and MP of the hind wing arise independently from the stem $R+M$; in the Inocelliidae and Raphidiidae MA and MP arise from the common stem $M$, after its separation from $R$. On the other hand, in none of the previously known extinct families, including Mesoraphidiidae, does MA in the fore wing arise far distad of the fork of MP, as it does in the Alloraphidiidae. This feature does occur in the Inocelliidae and Raphidiidae, but it is obviously of an independent origin.

The Alloraphidiidae provide additional evidence for the conclusion that in the Mesozoic era the snake-flies were a far more diverse group than now, representing still another line of evolution within the order. In addition to the family Mesoraphidiidae, which is known from the Jurassic of Turkestan, the family Baissopteridae is known from the Upper Jurassic of Trans Baikal; this includes species which had more venational branches and more cross veins than the Mesoraphidiidae or the existing families (Martynova, 196I). It is interesting to note, however, that MA arose in the hind wing of the Baissopteridae just as it does in the Mesoraphidiidae and the Alloraphidiidae (see plate 35). The excellent preservation of the Jurassic snake-flies from the USSR shows clearly that, apart from the wings, their body structure was remarkably like that of the existing families, even to the prothorax and ovipositor (Martynov, I925b, Martynova, I962). The Oligocene snake-flies (Baltic amber; Florissant and Creede Shales, Colorado) belong not only to Recent families but to existing genera, though these genera in the Tertiary show quite different distributional patterns from those which they possess now (Carpenter, 1936, 1956).

\section{EXPLANATION OF PLATE 35}

Fig. A. Mesoraphidia pterostigmalis Martynova, fore wing; Upper Jurassic, USSR (Kazakstan). Length of wing, $13 \mathrm{~mm}$. After Martynova, 1947.

Fig. B. Mesorophidia pterostigmalis Martynova, hind wing; Upper Jurassic, USSR (Kazakstan). Length of wing, $12 \mathrm{~mm}$. After Martynova, 1947.

Fis. C. Baissoptera martinsoni Martynova, fore wing; Upper Jurassic, USSR (Buryatskaya A.S.S.R.). Length of wing, $13 \mathrm{~mm}$. After Martynova, 1961.

Fig. D. Baissoptera koloznitsynae Martynova, hind wing; Upper Jurastic, USSR (Buryatskaya A.S.S.R.). Length of wing $12.5 \mathrm{~mm}$. After Martynova, 1961. 
The Permian snake-flies are little-known. ${ }^{1}$ Sojanoraphidia (Sojanoraphidiidae) from the Permian of the USSR (Marynova, I952) has a long, curved ovipositor like that of the Recent species but the venation of the single wing that is known does not have the basic Raphidiodean pattern. It possesses a very long subcosta extending almost to the apex, and a very narrow costal space. What is most striking is the structure of the basal part of the radial sector and MA, which resembles the condition found in the hind wings of the Mesoraphidiidae, Alloraphidiidae and Baissopteridae. Although the apparent origin of this wing from the thorax indicates that it is a fore wing, as it was designated by Martynova, I find it difficult to
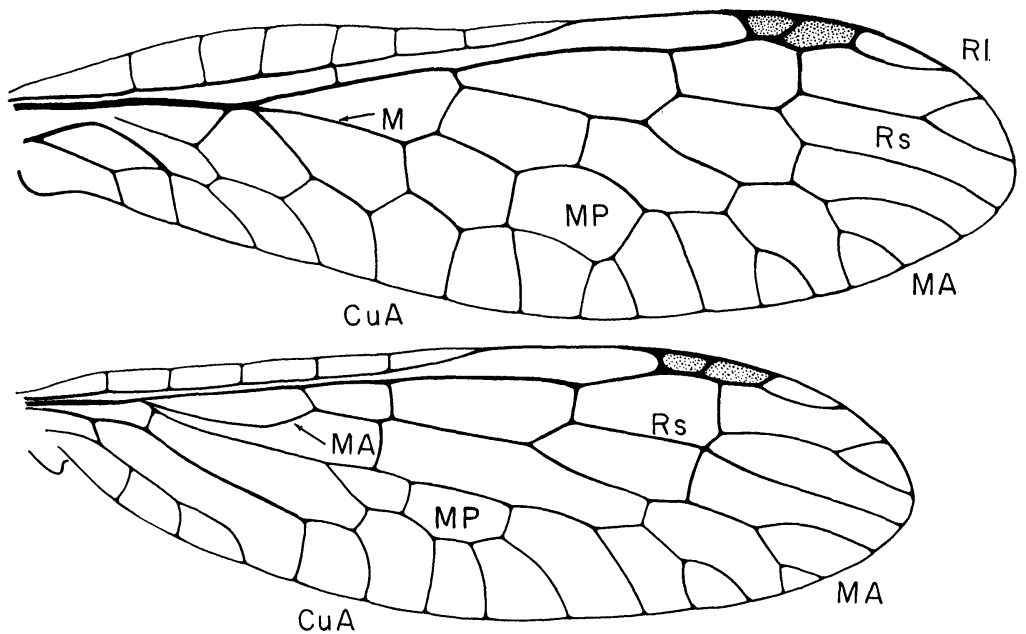

Figure 2. Raphidia americana Carpenter, fore and hind wings. Recent, Mexico (Carpenter, 1958).

believe that it is not the hind wing; at any rate, if it turns out to be the fore wing then quite clearly this is another very different line of the Raphidiodea from the others which are known in the fossil record. In fact, if it were not for the long, curved ovipositor, I would doubt that it could belong to the order.

I have serious doubts about the position of the families Lepalopteridae Martynova, from the Permian of USSR, and of the family

\footnotetext{
${ }^{1}$ The family Permoraphidiidae Tillyard from the Lower Permian of Kansas is almost certainly not a snake-fly but most likely an orthopterous insect, related to the Permelcanidae and Oedischiidae.
} 
Fatjanopteridae, from the Upper Carboniferous of USSR (Martynova, I96I). Neither of these families, each represented by a single species, seems to me to show in the wings the basic characteristics of the Raphidiodea. It is possible, of course, that like the Sojanoraphidiidae they could represent other radiating lines in the late Paleozoic, but they could equally well represent separate orders or suborders within the neuropteroid complex or, even, be members of the exopterygote series of insects. Until we know more of the wings and body structures of these insects, I consider their position uncertain even at the ordinal level.

Carpenter, F. M.

\section{REFERENCES}

1936. Revision of the Nearctic Raphidiodea (Recent and Fossil). Proc. Amer. Acad. Arts \& Sci., 71: 89-157.

1956. The Baltic Amber Snake-flies. (Neuroptera). Psyche, 63: 77-81.

1958. Mexican Snake-flies (Neuroptera: Raphidiodea). Psyche, 65: 52-58.

Martynov, A. V.

1925a. [Contributions] to the knowledge of fossil insects from Jurassic beds in Turkestan. 1. Raphidioptera. Bull. Acad. Sci. Russ. 19: 233-246.

1925b. [Contributions] to the knowledge of fossil insects from Jurassic beds in Turkestan. 2. Raphidioptera (continued), Orthoptera (s. 1.), Odonata, Neuroptera. ibid, 19: 569-598.

Martynova, O. M.

1947. Two New Raphidioptera from Jurassic Shales of Karatau. Dokl. Akad. Nauk. SSSR. 56(6): 635-637.

1952. Permian Neuroptera of the SSSR. Trudy Paleont. Inst. Akad. Nauk. SSSR. 40: 197-238.

1960. Die Kamelhalsfliegen aus dem Perm und Karbon. 11th Inter. Congr. Ent., Wien, 1: 302-304.

1961. Recent and Fossil Snakeflies. Paleont. Journ. 3 : 73-83.

1962. Raphidioptera, in Osnovy (B. B. Rohdendorf and others), Insecta; pp. 270-272. 

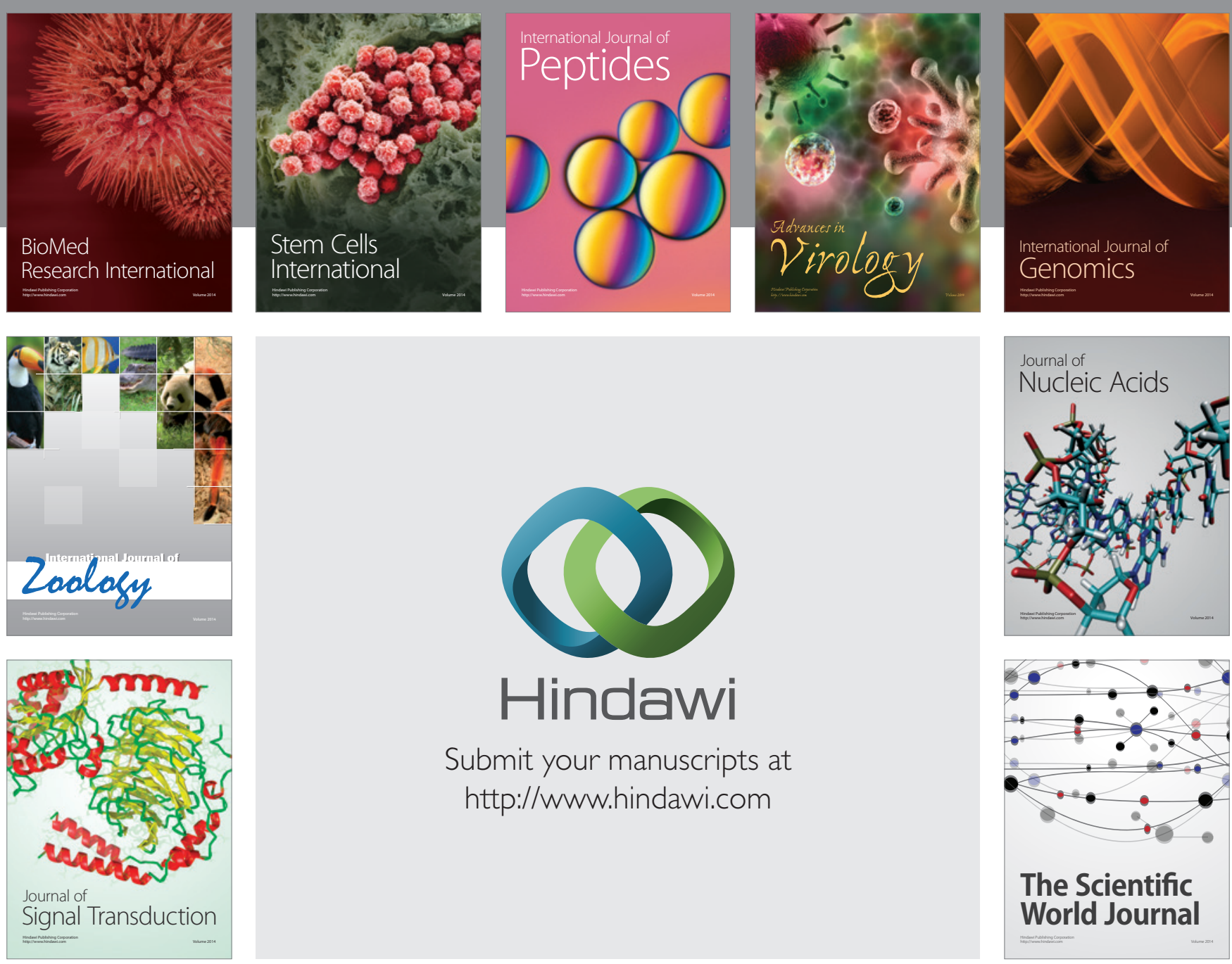

Submit your manuscripts at

http://www.hindawi.com
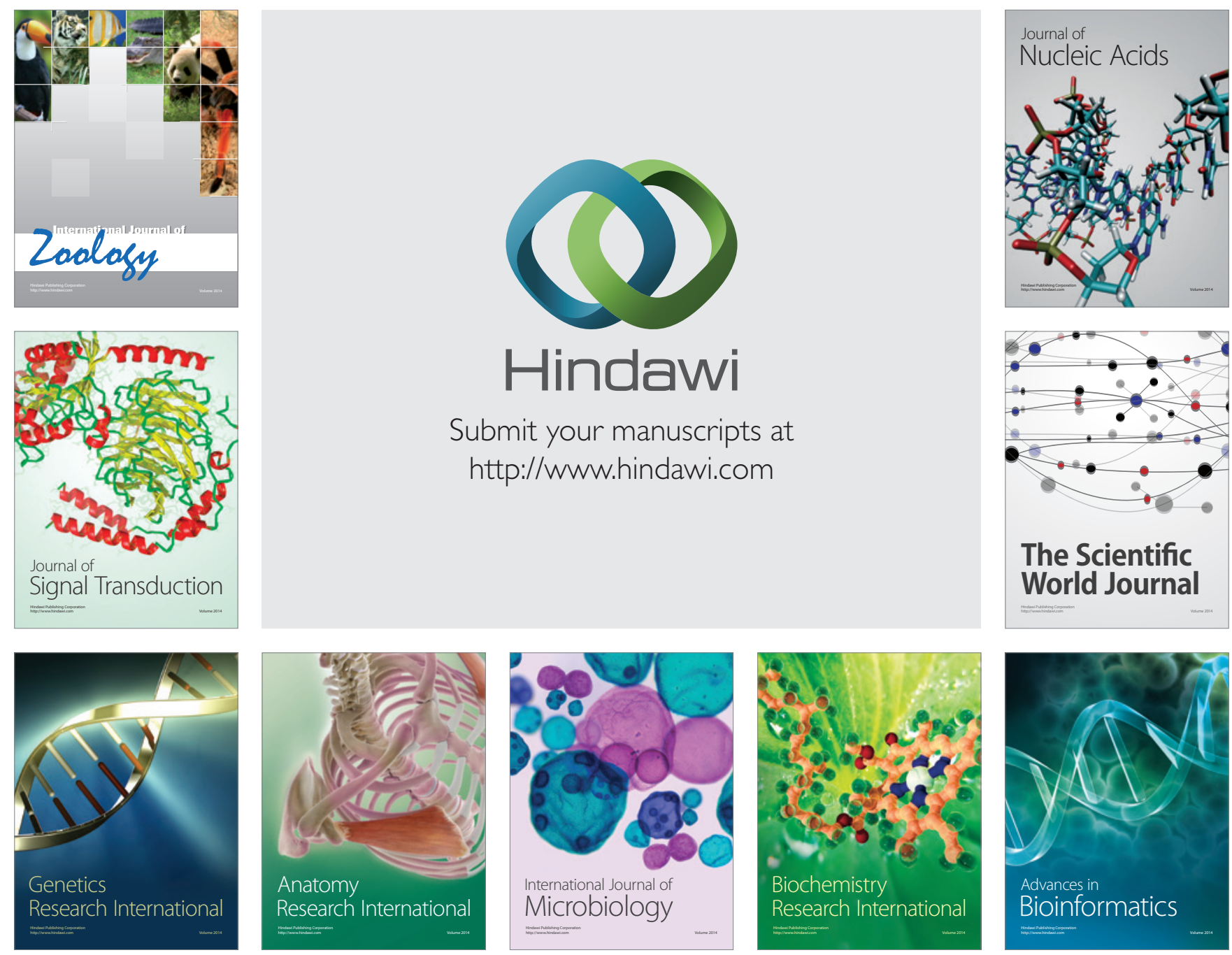

The Scientific World Journal
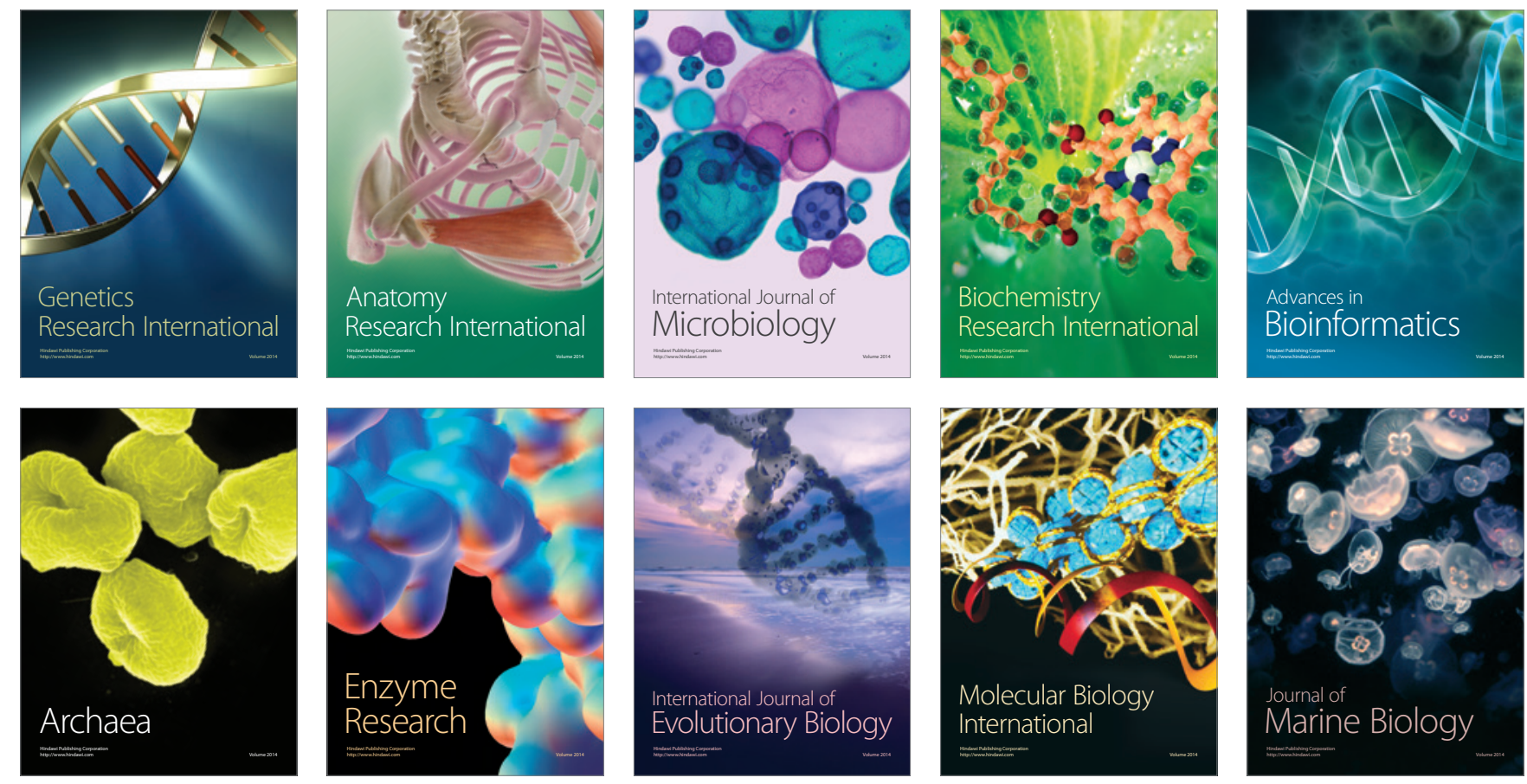